\title{
The Influence of Organisational Culture, Quality of Human Resources and Motivation on Employee Performance through Work Discipline at the Class IIA Batam Penitentiary
}

\author{
Adi Prasetyo ${ }^{1}$, Chablullah Wibisono ${ }^{2}$ Indrayani $^{3}$ \\ ${ }^{1}$ Postgraduate Student, Department of Management, Faculty of Economics, Universitas Batam, Batam, \\ Indonesia \\ ${ }^{2-3}$ Postgraduate Lecturer, Department of Management, Faculty of Economics, Universitas Batam, Batam, \\ Indonesia
}

Corresponding Author: Adi Prasetyo

\section{ABSTRACT}

The purpose of this study was to analyse the influence of organisational culture, quality of human resources and motivation on performance directly or through work discipline at the Class IIA Batam Penitentiary. This study uses primary data with a questionnaire, such as gender, age and length of work, in order to provide a clear picture of the characteristics of the respondents. This study uses a correlational method approach with a total sample of 95 samples. The research tool uses SEM-PLS, and the results showed that organisational culture had a positive and significant effect on discipline. The quality of human resources has a positive and significant effect on discipline. Motivation has a positive and insignificant effect on discipline. Organisational culture has a positive and insignificant effect on performance. The quality of human resources has a positive and insignificant effect on performance. Motivation has a positive and significant effect on performance. Discipline has a positive and significant effect on performance. Organisational culture indirectly significantly influences performance through organisational culture. The quality of human resources indirectly has a significant effect on performance through discipline. Indirect motivation has an insignificant effect on performance through discipline.
\end{abstract}

Keywords: Organisational Culture, HR Quality, Motivation, Discipline, Performance.

\section{INTRODUCTION}

One of the most critical assets of a company has a competent workforce or, in this case, employees. Employees are the primary driver of an organisation that is a factor in the success or failure of the organisation. To ensure optimal employee performance and retention, organisations need to consider various appropriate ways to reward employees for obtaining results that align with the company's overall vision and targets. Organisations will consider employee performance and loyalty to be the backbone of the organisation, which is very dependent on knowledge and awareness of the culture that includes them. In addition to culture will improve organisational behaviour, there is also a leading factor. It is also stated that the values and norms of employees identified by management will encourage employee performance improvement. Including awareness of quality, it will also help improve organisational and employee development. Optimisation of an employee's performance will be influenced by several factors such as lack of participation, affection and motivation to achieve the leader's goals. This is determined by the increase in 
employee absenteeism, unproductive time, and work completion percentage. Apart from the practical application of human resource management, these indicators will not only affect employee performance.

Each employee will give the best contribution and accept the responsibility of their work and the level of their performance achieved by consistently measuring the conditions and abilities that cover them. On the other hand, company management will pay attention to improving employee performance and welfare in various ideal ways. Human resource management that is directed and appropriate will produce significant progress for the company. - the encouragement of the workforce to work optimally in accordance with the targets that the company expects to be the most important key in achieving the achievements set by the company. However, the company may not allow the welfare of the workers to be neglected. Therefore, consistency is needed to maintain optimal performance. In other words, a motivation that precedes someone to enter an organisation is by giving what they want and rights. Therefore, the key to the success of managers/leaders is to mobilise their subordinates so that they are able to practice motivation theory and turn this theory into a compelling impetus for improving company performance. It is also mentioned that motivation is the energy to generate selfdrive among each employee, which will affect their behaviour, which in turn, the motivation will direct and maintain their behaviour towards the work environment.

Motivation encourages the inner side of employees to follow up on the stimulation of their respective demands or goals to satisfy their desires and make it applicable to others to produce the best service to customers (Setiadi \& Setiadi, 2016). The internal motivation of employees comes from the need for money, respect, power, and recognition. External motivation comes from family, co-workers and leaders. Motivation is divided into two, positive motivation and negative motivation.
Positive motivation denotes the process of influencing people by conferring the possibility of getting a reward, while negative motivation characterises the process of influencing a person through fear-forces such as losing recognition, money or position.

Furthermore, other motivation concepts such as intrinsic motivation and extrinsic motivation - intrinsic motivation drive employees' work that comes from within the workers in the form of awareness about the meaning of the work they do. Extrinsic motivation drives employees' work that comes from outside the worker's self in the form of a condition that requires working optimally.

Accordingly, we formulate problems related to the issues summarised at the outset and propose the following research questions:

1. Does organisational culture have a positive effect on employee discipline at the Class IIA Batam Penitentiary?

2. Does the quality of human resources positively affect the work discipline of employees at the Class IIA Batam Penitentiary?

3. Does motivation have a positive effect on employee discipline at the Class IIA Batam Penitentiary?

4. Does organisational culture have a positive effect on employee performance at the Class IIA Batam Penitentiary?

5. Does the quality of human resources positively affect employee performance at the Class IIA Batam Penitentiary?

6. Does motivation have a positive effect on employee performance at the Class IIA Batam Penitentiary?

7. Does discipline have a positive effect on employee performance at the Class IIA Batam Penitentiary?

8. Does organisational culture positively affect employee performance with work discipline as an intervening variable at the Class IIA Batam Penitentiary?

9. Does the quality of human resources positively affect employee performance with work discipline as an intervening 
Adi Prasetyo et.al. The influence of organisational culture, quality of human resources and motivation on employee performance through work discipline at the Class IIA Batam Penitentiary.

variable at the Class IIA Batam Batam Penitentiary?

10. Does motivation positively affect employee performance with work discipline as an intervening variable at the Class IIA Batam Penitentiary?

\section{LITERATURE REVIEW Organisational Culture}

Organisational culture denotes having a form of perception, which is accepted implicitly by the group and determines how the group feels, thinks, and reacts to diverse environments (Kreitner \& Kinicki, 2014). It also mentions a framework that guides daily behaviour for employees to make decisions and direct their actions to achieve organisational goals (Rivai, 2018:94), that characterises the values, principles, traditions, and ways of working that are shared by members of an organisation and influence the way they act (Robbins \& Coulter, 2018).

The characteristics of organisational culture are reflected in the following.

- Innovation and Risk-Taking - the extent to which employees are encouraged to be innovative and dare to take risks.

- Attention to detail - the extent to which employees carry out accuracy, analysis and attention to details.

- Outcome Orientation - the extent to which management focuses on results rather than on the techniques and processes employed to achieve those results.

- People Orientation - the extent to which management decisions consider the effect of these results on people in the organisation.

- Team Orientation - the extent to which work activities are organised in teams, not only on individuals.

- Aggressiveness - the degree to which people in the organisation are aggressive and competitive rather than relaxed.

- Stability - the extent to which organisational activities emphasise maintaining the status quo in comparison to growth.

\section{Quality of Human Resources}

Human resources characterise the integrated ability of the individual's thinking power and physical power (Hasibuan, 2017). It is also mentioned that behaviour and characteristics are determined by heredity and environment. Human Resources includes individuals who are referred to as managers, employees, employees, labourers or workers who work for the organisation (Wirawan, 2015). Like individuals in the organisation who make valuable contributions to achieving organisational goals (Soegoto, 2016).

We propose indicators of human resource quality as follows. First, Intellectual Quality (knowledge and Skills), which includes; a) knowledge and skills in science and technology in accordance with industrialisation guidelines; b) knowledge of languages, including national languages, regional languages and at least one foreign language. Second, the quality of education includes; a) educational ability at a higher level; b) the level of variety and quality of education and relevant skills by taking into account the dynamics of employment at the local, national and international levels.

\section{Motivation}

Motivation is a potential force that exists within a human being, which may be developed independently or developed by many external forces that revolve around monetary rewards and non-monetary rewards, which may affect the results of their performance positively or negatively (Winardi, 2016). It is also stated that motivation will question how to encourage subordinates to work hard by giving all the abilities and skills to realise their goals (Hasibuan, 2017). We propose the indicators of motivation referring to the concept presented by Rivai (2018), as follows. First, the need for achievement characterises the need to develop creativity, the need to improve abilities, the need to achieve the highest achievement and the need to work effectively and efficiently. Second, the need for affiliation signifies the 
need to be accepted, establish good relations between employees, and participate and cooperate. Third, the need for power signifies the need to exert influence, develop power and responsibility, and lead and compete.

\section{Work Discipline}

A tool used by leaders to communicate with employees to make them willing to change behaviour and as a way to increase one's awareness and willingness to comply with all applicable organisational rules and social norms (Rivai, 2018). Employee discipline requires communication tools, especially on specific warnings to employees who may not be willing to change their nature and behaviour. It is also mentioned as the implementation of management to strengthen organisational guidelines (Mangkunegara, 2015). Discipline arises from an individual's personal awareness to control him/herself not to do something contrary to the applicable provisions. The goal is that each individual organisation produces performance in accordance with the targets planned by the organisation. Therefore, we propose the dimensions and indicators of work discipline, which include the following.

a. Obedience to the time rules indicates compliance in working hours, leaving hours, and resting hours on time following the applicable company rules.

b. Comply with company rules: Basic rules on how to dress and behave in working within the company's scope.

c. Obedience to the rules of conduct at work indicates compliance with doing jobs according to the position, duties, responsibilities and how to relate to other work units.

d. Compliance with other regulations in the company indicates compliance with the rules that employees can and cannot do in the company.

\section{Performance}

Employee performance indicates the actual behaviour displayed by each employee as work performance produced in accordance with their role in the company (Rivai, 2018). It is also mentioned that performance indicates employees' work towards their contribution to the organisation over a certain period of time (Simamora, 2015). Performance is relevant to the quality and quantity of work achieved by an employee while carrying out their duties and in accordance with their responsibilities (Mangkunegara, 2017:131). Employee education level, initiative, work experience and motivation as predictors of performance. The results of one's work will provide feedback for the person to always be active in doing good cooperation. The best performance will result in good quality work and the amount of work according to the standards. We propose several indicators as a reference as follows:

1) Quality of work indicates the quality of work and conformity of results with work standards.

2) Promptness (speed) indicates completing tasks on time, and the work is achieved according to the target.

3) Initiative (initiative) characterises the ideas given to support the achievement of goals and can take advantage of free time.

4) Capability indicates the ability to complete the work as expected and completes it practically and neatly.

5) Communication is related to the ability to communicate well with superiors/leaders and fellow co-workers.

\section{RESEARCH METHOD}

This study uses a correlational research approach with cross-section data. The nature of this research is that the research explains the causal relationship between the variables through hypothesis testing. This is following the aim of the study to explain the causal relationship between exogenous variables and endogenous variables by testing hypotheses.

We apply primary and secondary data sources, such as distributing questionnaires for primary data, while 
secondary data includes the agency's history, vision, and mission. The research population was all Class IIA Batam Penitentiary employees, as many as 125 employees, while the research sample as many as 95 employees were taken using the Slovin formula randomly. The research data analysis technique used two statistical approaches, descriptive and inferential. Data analysis to test the hypothesis in this study is descriptive analysis and inferential analysis with Partial Least Square, while the data analysis tool uses Smart-PLS version 3.0.

Accordingly, we propose the following research hypotheses.

$\mathrm{H} 1$; Organisational culture has a positive effect on employee discipline at the Class IIA Batam Penitentiary.

$\mathrm{H} 2$ : The quality of human resources has a positive effect on the work discipline of employees at the Class IIA Batam Penitentiary.

H3: Motivation has a positive effect on employee work discipline at the Class IIA Batam Penitentiary.

H4: Organisational culture has a positive effect on employee performance at the Class IIA Batam Penitentiary.
H5: The quality of human resources has a positive effect on employee performance at the Class IIA Batam Penitentiary.

H6: Motivation has a positive effect on employee performance at the Class IIA Batam Penitentiary.

H7: Discipline has a positive effect on employee performance at the Class IIA Batam Penitentiary.

H8: Organisational culture positively affects employee performance with work discipline as an intervening variable at the Class IIA Batam Penitentiary.

H9: The quality of human resources has a positive effect on employee performance with work discipline as an intervening variable at the Class IIA Batam Penitentiary.

H10: Motivation positively affects employee performance with work discipline as an intervening variable at the Class IIA Batam Penitentiary.

\section{RESULT}

The study of the characteristics of 95 respondents shows that the majority of the characteristics of education are high school by $73.7 \%$, the majority of years of work 1319 years by $35.8 \%$, and the majority gender is male at $77.9 \%$.

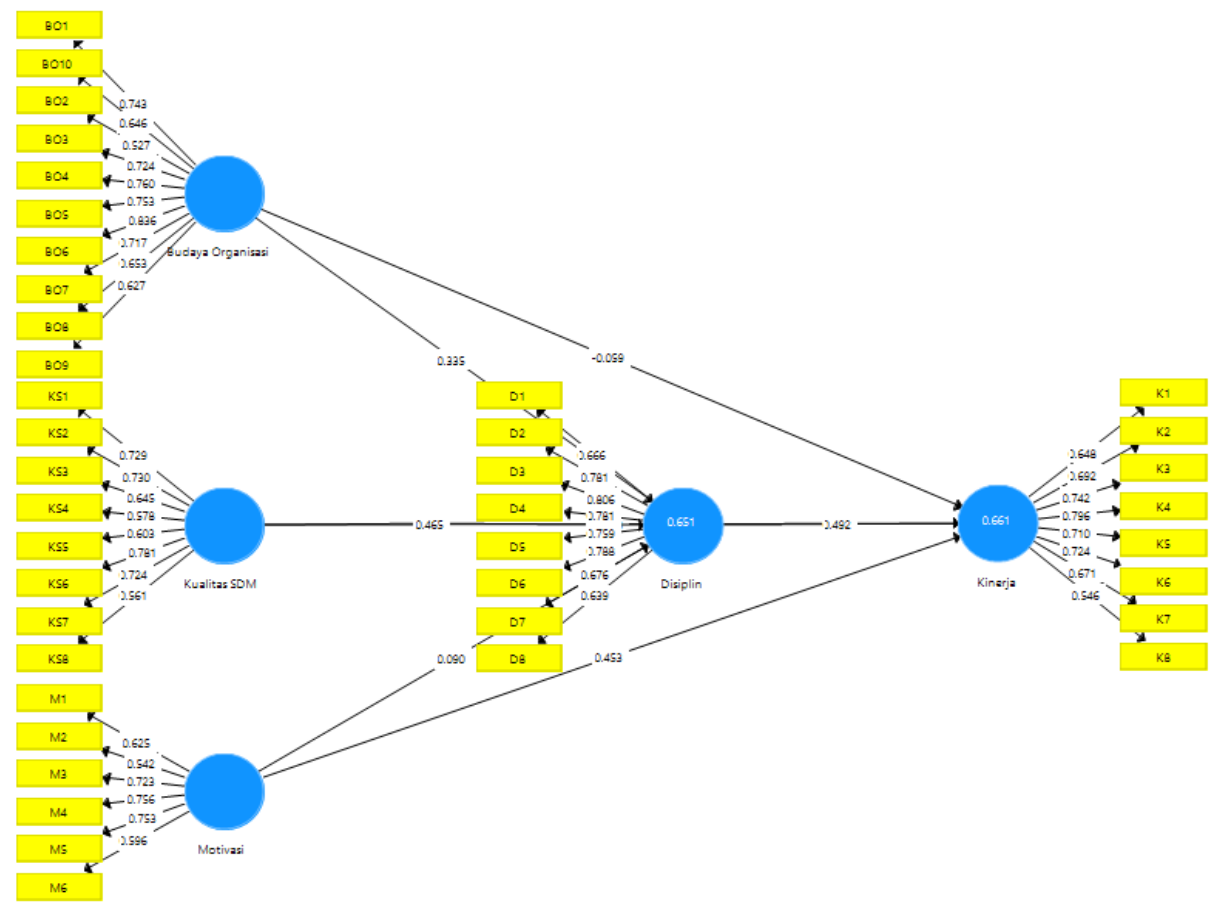

Figure 1. Loading Factor 
Adi Prasetyo et.al. The influence of organisational culture, quality of human resources and motivation on employee performance through work discipline at the Class IIA Batam Penitentiary.

Figure 1 depicts the results of the loading factor, which indicates that there are no indicators that have not achieved the loading factor of 0.5 , as shown. Several outer loading values of $>0.5$ are found for each research indicator, and the outer loading values of between 0.5 and 0.6 are deemed adequate to satisfy the convergent validity criteria of the research indicator.

Table 1 Composite Reliability

\begin{tabular}{|l|l|l|}
\hline No & Variable & Composite Reliability \\
\hline 1 & Organisational culture & 0.906 \\
\hline 2 & HR Quality & 0.867 \\
\hline 3 & Motivation & 0.829 \\
\hline 4 & Discipline & 0.906 \\
\hline 5 & Performance & 0.881 \\
\hline
\end{tabular}

While the composite reliability value for each construct exceeds 0.7 thus, the outer model analysis proceeds to the stage of outer model validity.

Table 2. Average Variance Extracted (AVE)

\begin{tabular}{|c|c|c|}
\hline No & Variable & AVE \\
\hline 1 & Organisational culture & 0.643 \\
\hline 2 & HR Quality & 0.603 \\
\hline 3 & Motivation & 0.551 \\
\hline 4 & Discipline & 0.504 \\
\hline 5 & Performance & 0.541 \\
\hline
\end{tabular}

The table above shows that the AVE value of each construct in the final model has reached a value of $>0.5$. Thus, the proposed structural equation model has met the convergent validity criteria

\begin{tabular}{|l|l|l|}
\multicolumn{1}{|c}{ Table 3. R Square } \\
\hline Discipline & R Square & R Square \\
\hline Performance & 0.651 & 0.639 \\
\hline
\end{tabular}

Based on Table 3. The R-Square value for the discipline variable is 0.651 , which indicates that 65.1 per cent of the impact of organisational culture, human resource quality, and motivation on discipline is explained by these factors. In contrast, 34.9 per cent is explained by other variables which are not examined in this study and the $\mathrm{R}$ Square value for the performance variable is 0.661 . This indicates that the percentage of organisational culture, human resource quality, motivation, and discipline influencing performance is 66.1 per cent, placing it in the moderate category. In comparison, the remaining 33.9 per cent can be explained by other variables that are not examined in this study.

\section{Direct Effect}

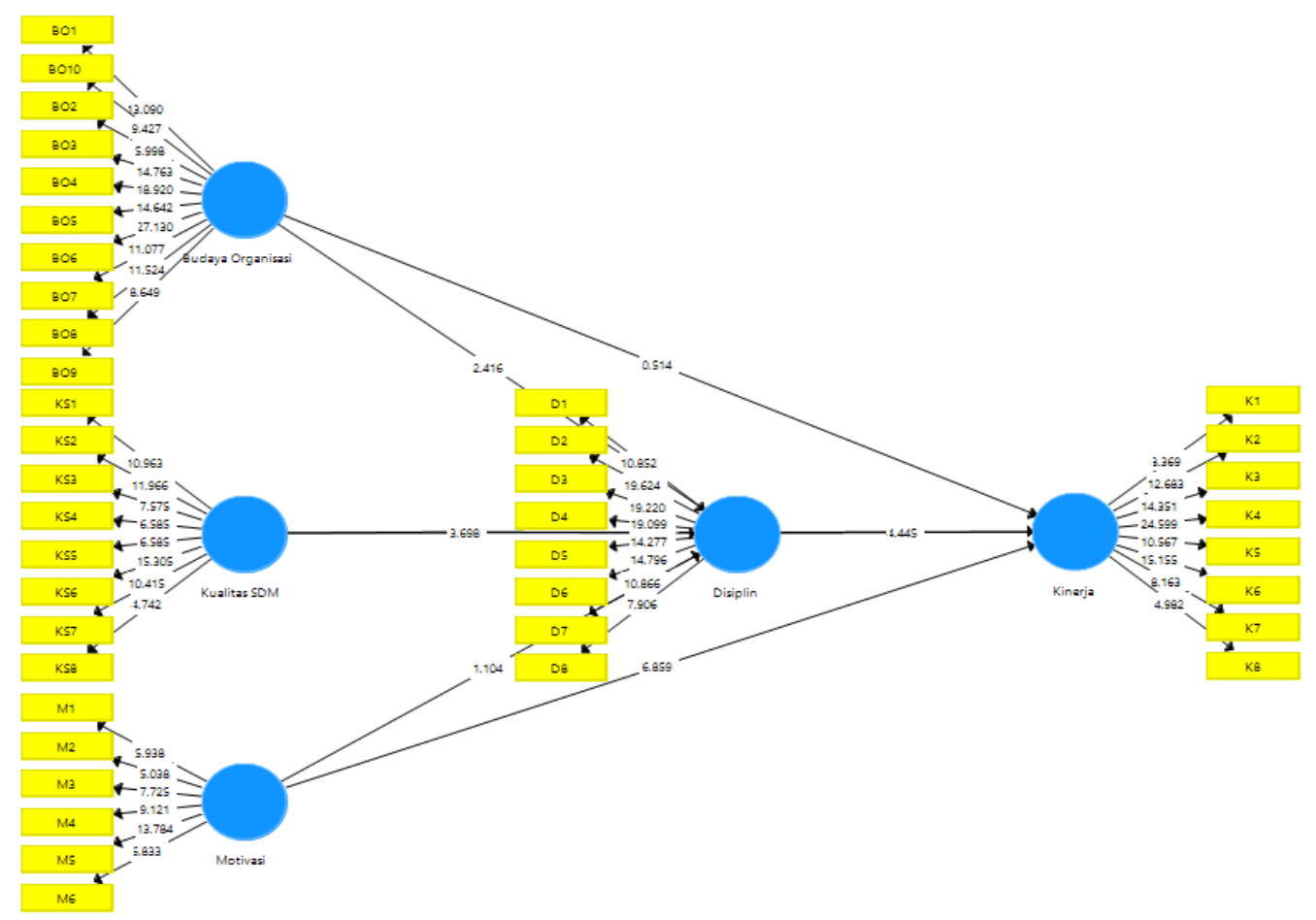

Figure 2. Path Coefficient between Variables. 
Adi Prasetyo et.al. The influence of organisational culture, quality of human resources and motivation on employee performance through work discipline at the Class IIA Batam Penitentiary.

Table 4. Path Coefficients

\begin{tabular}{|l|l|l|l|l|l|}
\hline & Original Sample & Sample Mean & Standard Deviation & T Statistics & P Values \\
\hline Organisational Culture $\rightarrow$ Discipline & 0.335 & 0.336 & 0.139 & 2.416 & 0.016 \\
\hline HR Quality $\rightarrow$ Discipline & 0.465 & 0.467 & 0.126 & 3.698 \\
\hline Motivation $\rightarrow$ Discipline & 0.090 & 0.092 & 0.082 & 0.000 \\
\hline Organisational Culture $\rightarrow$ Performance & -0.059 & -0.048 & 0.116 & 1.104 & 0.270 \\
\hline HR Quality $\rightarrow$ Performance & 0.068 & 0.069 & 0.123 & 0.514 & 0.608 \\
\hline Motivation $\rightarrow$ Performance & 0.453 & 0.460 & 0.066 & 0.557 & 0.578 \\
\hline Discipline $\rightarrow$ Performance & 0.492 & 0.482 & 0.111 & 6.859 & 0.000 \\
\hline
\end{tabular}

The following findings are derived from table 4. First, given that organisational culture has a coefficient of 2.416 , it has a positive impact on discipline, and a $\mathrm{p}$-value of $0.016<0.05$ is significant. Thus, organisational culture has a positive and significant effect on discipline. Second, given that the coefficient value of human resource quality is 3.698 , it is evident that human resource quality positively impacts discipline, as shown by a p-value of $0.000<$ 0.05 . As a result, it can be stated that human resource quality has a positive and significant impact on the discipline. Third, since motivation has a coefficient of 1.104, it positively impacts discipline, and the pvalue of $0.270>0.05$ indicates that motivation has a positive but insignificant effect on discipline. Fourth, since organisational culture has a coefficient value of 0.514 , it positively impacts performance, and a significant value of
$0.608>0.05$ is not significant, it can be inferred that organisational culture has a positive but insignificant effect on performance. Fifth, since the coefficient value of human resource quality, is 0.557 , it is evident that human resource quality positively impacts performance, and a pvalue of $0.578>0.05$ is not significant. As a result, it may be stated that human resource quality has a positive but insignificant impact on performance. Sixth, since motivation has a coefficient of 6859 , it has a positive impact on performance, and $p$ values $0.000<0.05$ is significant. Thus, motivation has a positive and significant effect on performance. Seventh, since discipline have a positive impact on performance and a p-value of $0.000<0.05$ is significant, it may be inferred that discipline has a positive and significant effect on performance.

\section{Indirect Effect}

Table 5. Indirect effect

\begin{tabular}{|l|l|l|l|l|l|}
\hline & $\begin{array}{l}\text { Original } \\
\text { Sample }\end{array}$ & $\begin{array}{l}\text { Sample } \\
\text { Mean }\end{array}$ & $\begin{array}{l}\text { Standard } \\
\text { Deviation }\end{array}$ & T Statistics & P Values \\
\hline Organisational culture $\rightarrow$ Discipline $\rightarrow$ Performance & 0.165 & 0.158 & 0.069 & 2.394 & 0.016 \\
\hline HR Quality $\rightarrow$ Discipline $\rightarrow$ Performance & 0.229 & 0.229 & 0.091 & 2.523 & 0.012 \\
\hline Motivation $\rightarrow$ Discipline $\rightarrow$ Performance & 0.044 & 0.044 & 0.041 & 1.071 & 0.285 \\
\hline
\end{tabular}

The following table summarises the findings of the indirect impact test on the examined latent variables, with an indirect impact of 2,394 on performance through discipline and a p-value of $0.016<0.05$, which meant organizational culture has a significant indirect influence on performance via organizational culture. In other words, organizational culture has a significant impact on discipline and performance relationship. Furthermore, the indirect impact of human resource quality on performance via discipline is 2,523 , with a p-value of $0.12<0.05$, indicating that human resource quality significantly influences performance through discipline indirectly. In other words, significant discipline serves as mediation between human resource quality and performance. Finally, motivation's indirect impact on performance via discipline is 1.071 , with a p-value of $0.285>0.05$, indicating that motivation does not influence performance directly but through discipline. In other words, discipline has a relatively minor role 
Adi Prasetyo et.al. The influence of organisational culture, quality of human resources and motivation on employee performance through work discipline at the Class IIA Batam Penitentiary.

in mediating the link between motivation and performance.

\section{Sobel Test Results}

Applied the Sobel test by testing the strength of the indirect effect of the independent variable $(\mathrm{X})$ on the dependent variable $(Z)$ through the intervening variable (Y). Indirect effect by multiplying the path coefficient of each relationship.

\section{Sobel Test of Work Culture on Performance through Discipline}

Testing the hypothesis of the indirect effect of work culture on performance through work discipline as an intervening variable using the test calculator aid program can be presented in the following table.

Table 6. Sobel Test of Work Culture on Performance through Discipline

\begin{tabular}{|c|c|c|c|c|c|}
\hline & Input: & & Test statistic: & Std. Error: & $p$-value: \\
\hline$a$ & 0.335 & Sobel test: & 2.11731951 & 0.07784371 & 0.03423274 \\
\hline$b$ & 0.492 & Aroian test: & 2.07691649 & 0.07935803 & 0.03780927 \\
\hline$S_{a}$ & 0.139 & Goodman test: & 2.16017606 & 0.07629934 & 0.03075904 \\
\hline & 0.111 & Reset all & \multicolumn{3}{|c|}{ Calculate } \\
\hline
\end{tabular}

Based on Table 6, the Calculation results for the Sobel test based on the table above can be seen the p-value of the mediation effect. Because the p-value = 0.034 is smaller than 0.05 , it can be concluded that the mediation coefficient is 0.034 significant and means that there is an influence of discipline mediation in mediating the relationship between organizational culture and performance.

\section{Sobel Test of HR Quality on Performance through Discipline}

The hypothesis testing the indirect effect of HR quality on performance through work discipline as an intervening variable using the test calculator aid program can be presented in the following table.

Table 7. Sobel Test of HR Quality on Performance through Discipline

\begin{tabular}{|c|c|c|c|c|c|}
\hline & Input: & & Test statistic: & Std. Error: & $p$-value: \\
\hline$a$ & 0.465 & Sobel test: & 2.83611457 & 0.0806667 & 0.00456661 \\
\hline$b$ & 0.492 & Aroian test: & 2.79442444 & 0.08187017 & 0.00519922 \\
\hline$s_{\mathrm{a}}$ & 0.126 & Goodman test: & 2.8797281 & 0.079445 & 0.00398018 \\
\hline & 0.111 & Reset all & \multicolumn{3}{|c|}{ Calculate } \\
\hline
\end{tabular}

Based on Table 7, the Calculation results for the Sobel test based on the table above can be seen the p-value of the mediation effect. Because the $p$-value $=$ 0.0045 is smaller than 0.05 , it can be concluded that the mediation coefficient of 0.0045 is significant and means that there is an influence of discipline mediation in mediating the relationship between HR quality and performance.

\section{Sobel Test of Motivation on Performance through Discipline}

The hypothesis tested the indirect effect of motivation on performance through work discipline as an intervening variable using a program that helps test calculators in the following table. 
Adi Prasetyo et.al. The influence of organisational culture, quality of human resources and motivation on employee performance through work discipline at the Class IIA Batam Penitentiary.

Table 8. Sobel Test of Motivation on Performance through Discipline

\begin{tabular}{|c|c|c|c|c|c|}
\hline & Input: & & Test statistic: & Std. Error: & $p$-value: \\
\hline$a$ & 0.090 & Sobel test: & 1.06538437 & 0.04156246 & 0.28670203 \\
\hline$b$ & 0.492 & Aroian test: & 1.04072061 & 0.04254744 & 0.29800524 \\
\hline & 0.082 & Goodman test: & 1.09188908 & 0.04055357 & 0.27488186 \\
\hline & 0.111 & Reset all & \multicolumn{3}{|c|}{ Calculate } \\
\hline
\end{tabular}

The p-value for the mediation effect is displayed in Table 8 due to the Sobel test calculation. Because the p-value is higher than 0.05 , the mediation coefficient of 0.2867 is not significant, indicating that disciplinary mediation does not mediate the relationship between motivation and performance.

\section{DISCUSSION \& CONCLUSION}

The findings indicated that the $\mathrm{t}-$ count value was 2.416 and the p-value was (0.05), which was statistically significant. That is, organisational culture has a positive and significant impact on performance. The effect of organisational culture on employee performance may be explained by many organisational factors that encourage employee involvement in initiatives and innovations. Moreover, workers have defined organisational objectives and are rewarded depending on their success, which encourages employees to pay attention to information regarding the company's growth. Additionally, Oskar's (2015) study demonstrates a positive relationship between organisational culture factors and organisational performance. Finally, organisational culture and measures of professionalism are intrinsically tied. Professionalism is the form of admiration for a professional employee who is devoted to his or her job, capable of working professionally, punctual, and disciplined.

The findings indicated that the $\mathrm{t}$ count value was 3.698 , and the p-value was $(0.05)$. In this instance, organisational culture has a positive and significant impact on performance. A higher standard of human resources (HR) may result in increased work discipline. According to the study's findings, the quality of human resources affects the discipline adopted. In this instance, human resource quality has a direct impact on employee work discipline. Qualified workers are assets that may assist organisations in improving their performance, and highly qualified human resources will be more disciplined in their jobs. The findings of this study corroborate Mahiro's prior research (2016).

The findings indicated that the $\mathrm{t}$ count value was 1.104 , and the p-value was not significant $(>0.05)$. This indicates that organisational culture has a positive but insignificant impact on performance. This implies that the more motivated an individual is, the more disciplined that employee is. Employees that are motivated will have a positive attitude; naturally, discipline will improve as well. According to descriptive data from the study, the most significant level of work motivation is shown by workers who constantly attempt to finish assigned tasks regardless of how tough they are and who also concentrate on completing all assigned jobs. The findings of this study corroborate those of Anggorowati and Suhartini (2012), who found that motivation had an indirect effect on nurses' performance through work discipline. Employees that are highly motivated at work are more compliant with their organisation's rules. Therefore, workers' disciplined attitudes may help them perform better because disciplined employees spend more time at work, enabling work to be finished on time. Similarly, in line with Susanty and Baskoro's (2012) findings, highly motivated workers also have a high level of work discipline, so their performance will improve as well.

The t-count value of 0.514 and the $p$ value of $(0.05)$ were not significant. That is, organisational culture has a small but 
favourable impact on performance. However, without positive employee relationships, the organisational culture will be ineffective - to foster an organisational culture, all organisational actors must be motivated by a sense of need and do their duties with sincerity. In this sense, each employee will work responsibly to complete his assigned tasks, enabling all workers to participate actively in accomplishing the organisation's objectives.

The t-count value of 0.557 and the $p$ value of $>0.05$ were not significant. This implies that the quality of human capital has a small but favourable impact on performance. The assistance of high-quality human resources affects the organisation's performance and management. For agency managers, human resources refer to the resources, potential, strengths, and talents inherent in human beings, which define the attitude and quality of human people who are capable of excelling and contributing to the agency's effectiveness, efficiency, and independence.

In this instance, human resources contribute to the agency's performance improvement, with performance serving as a proxy for the degree to which the organisation's management targets are met. A good manager will always strive to enhance his or her company, eventually resulting in tremendous business growth. Given the significant and positive relationship between the quality of human resource variables and the agency's performance, the agency should pay special attention to the quality of human resources responsible for managing the institution, while not as significant, determining the agency's performance in this area. This is because the quality of human resources is critical to achieving a goal. Without dependable human resources, an organisation's objectives are most likely to be missed since the success of anything is entirely dependent on who manages it. If only those who use it were untrustworthy, it undoubtedly serves a purpose.
The t-count value of 6859 and the $\mathrm{p}$ value of (0.05) were found to be significant. That is, motivation has a significant and positive impact on performance. This implies that the more motivated employees are, the better their performance will be. Human psychological states and mental attitudes that generate energy promote activity and drive behaviour toward meeting requirements. Highly motivated employees also report a high level of job satisfaction. This research is consistent with Kiruja and Mukuru's (2013) findings, which suggest that although the results of this study demonstrate that work motivation directly impacts employee performance, it also has an indirect effect on employee performance through discipline and work motivation.

The t-count value was 4.445 , and the p-value (0.05) was significant. That is, organisational culture has a significant and positive impact on performance. This indicates that the work discipline variable is improving, which means that employee performance will improve as well, and based on the questionnaire findings, it is clear that the work discipline has an impact on employee performance. This condition indicates that the respondent's response to the work discipline variable is favourable due to a dispute or employee issue with working hours that have an adverse effect on employee performance. Employees must enhance their time management discipline. Employees do not make a concerted effort to fulfil their obligations and responsibilities in carrying out the job assigned by their leadership in their various areas. The study's findings indicate that the work discipline variable has a favourable effect on the performance variable. This is demonstrated by Singodimendjo's concept in Sutrisno (2011), which states that the better the discipline of an employee/work employee, the better the job (performance) can be accomplished. Without the support of strong employee discipline, an institution or agency would struggle to accomplish its objective, which is to achieve optimum employee performance. Thus, discipline is 
critical to a business's success in attaining its objectives. The findings of this study corroborate Thaief et al.'s research (2015), which suggests that good employee performance is contingent upon a high level of work discipline in planning, executing, and assessing the employee's job. Increased job motivation will definitely result in an improvement in staff performance.

The results obtained that the indirect effect of organisational culture on performance through discipline with a pvalue of $(<0.05)$, then organisational culture indirectly significantly influences performance through organisational culture. In everyday people's lives can not be separated from the cultural ties that are created. Cultural ties are created by the community concerned, whether in the family, organisation, business or nation. Culture distinguishes people from one another in the way they interact and act to complete a job. Culture binds members of community groups into a unified view that creates uniformity in behaviour or action. Over time, culture must be formed within the organisation and can also be felt helpful in contributing to the organisation's effectiveness as a whole. Organisational culture is the basic pattern of values, expectations, habits, and beliefs shared by all organisation members to carry out tasks to achieve organisational goals.

The study results obtained that the quality of human resources indirectly influenced performance through discipline with a p-value of $(<0.05)$, the quality of human resources indirectly significantly affected performance through discipline. With the support of good quality human resources, it will affect the organisation's performance and management. The quality of human resources is the resources or potential, or strengths or abilities that exist in humans, which determine the attitudes and qualities of humans who are able to excel and make cooperatives effective and efficient and independent. Human resources play a role in improving performance, where the performance can serve as a measure of the extent to which organisational goals set by the organisation's management are achieved. Good management will always try to improve its business, which ultimately leads to increased business development. Seeing that there is a significant and positive influence between the quality of HR variables on the performance variable, then the management should pay special attention to the quality of human resources who are responsible for managing HR because even though the influence is not so significant, this variable will determine the performance in the organisation of agency environment.

The study results obtained an indirect effect of motivation on performance through discipline with a p-value of (> 0.05 ), and then motivation indirectly had an insignificant effect on performance through discipline. The study results show that the motivation variable does not significantly affect performance through discipline. With motivation, it will not necessarily improve performance by increasing employee work discipline. The motivation felt by employees will not have an impact on their performance even though work discipline is improved. The lack of precise work motivation given is the main reason for the insignificant direct and indirect influence of motivational variables that do not affect performance.

\section{Acknowledgement: None}

\section{Conflict of Interest: None}

\section{Source of Funding: None}

\section{REFERENCES}

1. Aspan, H., Wahyuni, E. S., Effendy, S., Bahri, S., Rambe, M., \& Saksono, F. (2019). The Moderating Effect of Personality on Organizational Citizenship Behavior: The Case of University Lecturers. International Journal of Recent Technology and Engineering (IJRTE), 412-416.

2. Hasibuan, S. (2017). Manajemen Sumber Daya Manusia. Jakarta: Bumi Aksara. 
Adi Prasetyo et.al. The influence of organisational culture, quality of human resources and motivation on employee performance through work discipline at the Class IIA Batam Penitentiary.

3. Indrayani, \& Al Qarny, A. (2020). Factors Affecting Work Satisfaction and Employee Performance in Automotive Industrial Chain. International Journal of Economics and Business Administration, Volume VIII, Issue 2, 317-325.

4. Kreitner, R., \& Kinicki, A. (2014). Perilaku Organisasi. Jakarta: Salemba Empat.

5. Mangkunegara, A. (2015). Evaluasi Kinerja Sumber Daya Manusia. Bandung: Refika Aditama.

6. Rivai, V. (2018). Manajemen Sumber Daya Manusia untuk Perusahaan. Jakarta: Raja Grafindo Persada.

7. Robbins, S., \& Coulter, M. (2018). Manajemen. Jakarta: Erlangga.

8. Setiadi, N. (2017). Perilaku Konsumen. Jakarta: Kencana Pedana Media Grup.

9. Simamora, H. (2015). Manajemen Sumber Daya Manusia. Yogyakarta: STIEY.

10. Sugiyono. (2018). Metode Penelitian Bisnis. Bandung: Alfabeta.
11. Wahyuni, E., Fachrudin, K., \& Silalahi, A. (2019). An Empirical Study on Women's Financial Behavior: Case Study of Female Postgraduate Students in Medan, Indonesia. International Journal of Research Culture Society, 3(11), 155-159.

12. Wibisono, C., Nurhatisyah, \& Gustiawan, F. (2018). Work motivation and leadership on the performance of employees as predictors of organisational culture in broadcasting commission of Riau Islands province, Indonesia. Management Science Letters, 247-258.

13. Winardi. (2016). Kepemimpinan dalam Manajemen. Jakarta: Rhineka Cipta.

How to cite this article: Prasetyo A, Wibisono $\mathrm{C}$, Indrayani. The influence of organisational culture, quality of human resources and motivation on employee performance through work discipline at the Class IIA Batam Penitentiary. International Journal of Research and Review. 2021; 8(7): 105-116. DOI: https:// doi.org/10.52403/ijrr.20210715 